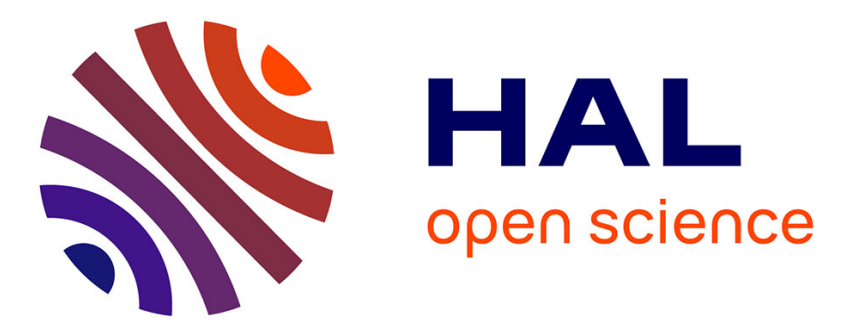

\title{
Unravelling the root zone of ultramafic-hosted black smokers-like hydrothermalism from an Alpine analog
}

Rémi Coltat, Yannick Branquet, Pierre Gautier, H. Campos Rodriguez, Marc

Poujol, Ewan Pelleter, Sean Mcclenaghan, Gianreto Manatschal, Philippe

Boulvais

\section{To cite this version:}

Rémi Coltat, Yannick Branquet, Pierre Gautier, H. Campos Rodriguez, Marc Poujol, et al.. Unravelling the root zone of ultramafic-hosted black smokers-like hydrothermalism from an Alpine analog. Terra Nova, 2019, 31 (6), pp.549-561. 10.1111/TER.12427 . insu-02294388

\section{HAL Id: insu-02294388 \\ https://hal-insu.archives-ouvertes.fr/insu-02294388}

Submitted on 23 Sep 2019

HAL is a multi-disciplinary open access archive for the deposit and dissemination of scientific research documents, whether they are published or not. The documents may come from teaching and research institutions in France or abroad, or from public or private research centers.
L'archive ouverte pluridisciplinaire HAL, est destinée au dépôt et à la diffusion de documents scientifiques de niveau recherche, publiés ou non, émanant des établissements d'enseignement et de recherche français ou étrangers, des laboratoires publics ou privés. 
MR RÉMI COLTAT (Orcid ID : 0000-0002-9474-1584)

Article type : Paper

\title{
Unravelling the root zone of ultramafic-hosted black smokers-like hydrothermalism from an Alpine analog
}

\author{
R. Coltat ${ }^{1 *}$, Y. Branquet ${ }^{1,2}$, P. Gautier ${ }^{1}$, H. Campos Rodriguez ${ }^{1}$, M. Poujol ${ }^{1}$, E. Pelleter ${ }^{3}$, S. \\ McClenaghan $^{4}$, G. Manatschal ${ }^{5}$, P. Boulvais ${ }^{1}$
}

${ }^{1}$ Univ Rennes, CNRS, Géosciences Rennes - UMR 6118, F-35000 Rennes, France

${ }^{2}$ Institut des Sciences de la Terre d'Orléans, UMR 7327, Université Orléans, 45234 Orléans, France

3 IFREMER Centre de Brest, DRO/GM, Plouzané, 29280, France

${ }^{4}$ Department of Geology, Trinity College Dublin, Dublin 2, Ireland; Irish Centre for Research in Applied Geosciences

5 Institut de Physique du Globe de Strasbourg, EOST-CNRS UMR 7516, Université de Strasbourg, 67084 Strasbourg, France

*Corresponding author: Rémi Coltat, remi.coltat@univ-rennes1.fr, +33 (0) 674491366

\section{Abstract}

Mid-Ocean Ridges host various types of hydrothermal systems including high-T black-smokers found in ultramafic rocks exhumed along slow spreading ridges. These systems are mostly described in two dimensions as their exposure on the present-day seafloor lacks the vertical dimension. One way to understand these systems at depth is to study their fossilized equivalents preserved on-land. Such observation can be done in the Platta nappe, Switzerland, where a

This article has been accepted for publication and undergone full peer review but has not been through the copyediting, typesetting, pagination and proofreading process, which may lead to differences between this version and the Version of Record. Please cite this article as doi: 10.1111/TER.12427

This article is protected by copyright. All rights reserved 
Jurassic-aged mineralized system is exposed in 3D. Serpentinites host a Cu-Fe-Ni-Co-Zn-rich mineralization made of sulfides, magnetite and Fe-Ca-silicates either replacing serpentinites or within stockwork. Fe-Ca-silicates, abundant at the deepest levels, vanish in the mineralization close to the paleo-detachment. Fluids were channelized along mafic dykes and sills acting as preferential drains. Warm carbonation $\left(\sim 130^{\circ} \mathrm{C}\right)$ is the latest hydrothermal record. We propose that this system is an analog to the root zone of present-day serpentinite-hosted hydrothermal systems such as those found along the Mid-Atlantic Ridge.

\section{Introduction}

Mid-Ocean Ridges (MORs) are places where deformation-assisted fluid-rock interactions play an important role in elemental mobility (Rona and Scott, 1993). At (ultra)slow-spreading ridges where mantle exhumation is favored by the presence of detachment faults (i.e. oceanic core complexes; Tucholke et al., 1998), these interactions lead to serpentinization of peridotite, venting of hydrothermal fluids with related mineralization, and ophicalcitization.

Active ultramafic-hosted black-smoker systems (UHS) are characterized by a Cu-Co-Zn-Au-(Ni) enrichment and high contents in $\mathrm{CH}_{4}$ and $\mathrm{H}_{2}$ in the venting fluid (Charlou et al., 2002). At the Mid-Atlantic Ridge (MAR), these UHS have been described for two decades through mineralogical (Hannington et al., 1995; Marques et al., 2006), geochemical (Herzig et al., 1998; Douville et al., 2002) and tectonic studies (McCaig et al., 2007; McCaig et al., 2010). However, due to restricted access to the seafloor, the understanding of their hydrothermal plumbing system, especially the root zone, (i.e. the mineralized portion below the seafloor) remains limited and speculative (Fouquet et al., 2010) (Fig. 1).

Ocean-Continent Transitions (OCTs) display similarities with oceanic realms: mantle exhumation along detachment faults (Boillot et al., 1987), presence of mafic magmatism and high geothermal gradients. Hence, fossil OCTs found in orogenic belts are promising targets to study oceanic hydrothermal processes (e.g. Alt et al., 2018). Here we present the geometric, mineralogical, geochemical and geochronological characteristics of a serpentinite-hosted hydrothermal system now exposed in the Platta nappe (Fig. 2, 3). We propose that this system, active during the Jurassic, represents the root zone of a UHS similar to those found along the MAR.

\section{Geological setting}


The Platta nappe (Grisons, SE Switzerland) exposes the Jurassic OCT of the Adriatic plate and belongs to the South Pennine Alpine units (Fig. 2A). Jurassic mantle exhumation was accommodated along detachments faults (Froitzheim and Manatschal, 1996) and accompanied by mafic magmatism (Fig. 2B; Desmurs et al., 2002) dated at 161 $1 \mathrm{Ma}$ (U-Pb on zircon;

Schaltegger et al., 2002). Evidence of hydrothermal circulation is recorded through alteration of mafic rocks (e.g. rodingitization and epidotization), formation of ultramafic-hosted mineralized systems (e.g. Marmorera-Cotschen, Fig. 3) and ophicalcitization (Coltat et al., 2019). The end of the rifting phase is marked by deposition of the Radiolarian Chert Formation dated between 166 and $147 \mathrm{Ma}$ (Bill et al., 2001). During the Cretaceous, tectonic inversion triggered the subduction of the Tethyan realm and subsequent continental collision resulting in thickening through W-NWvergent nappe stacking (D1 phase, Froitzheim et al., 1994). The Platta nappe was only affected by a low-temperature prehnite-pumpellyite metamorphism $\left(<300^{\circ} \mathrm{C}\right.$; Dunnoyer de Segonzac and Bernoulli, 1976; Ferreiro-Mahlmänn, 1994). During the Cenozoic, N-S-oriented shortening (D3 phase) resulted in the formation of large-scale E-W folds and N-vergent thrusts (Epin, 2017).

\section{Sampling and methods}

The serpentinite-hosted mineralization is exposed along the Marmorera-Cotschen cliff ( 600m-high; Fig. 3A) where detailed structural mapping and petro-structural analyses have been carried out. The Snake Pit outcrop is close to the paleo-detachment plane (Fig. 3B). A total of 75 thin sections and 9 polished mounts have been prepared from samples representative of the various hydrothermal assemblages: host serpentinites, Fe-Ca-silicates, semi-massive sulfides, $\mathrm{Cu}$-rich massive sulfides (Cu-rich MS) and ophicalcites.

\section{Results}

\section{Geometry of the mineralized zones}

The Marmorera Cotschen Hydrothermal Systems (MCHS) is hosted in the serpentinized footwall of a top-to-the-W Jurassic detachment that juxtaposes basalts onto serpentinites (Epin, 2017); the basalts being altered to a greenschist assemblage at their base (Fig. 3A, B). The mineralization occurs along the cliff as sporadic thin oxidized reddish corridors and patches (Fig. 3A, B). It reaches its maximum width at the gossan structure (i.e. oxidized zone after primary sulfides) of Cotschen (Fig. 3B). Mineralization is locally spatially associated with highly altered 
mafic dyke-like intrusions oriented sub-parallel to the detachment (Fig. 3C-F). Moving away from the intrusions, host serpentinites show a petrographic zonation: $\mathrm{Cu}$-rich massive to semi-massive sulfides evolve toward Fe-Ca-silicates stockwork and pervasive replacement and then to barren serpentinite (Fig. 3E, 4). Close to the detachment, the mineralized serpentinite is crosscut by calcite veins.

Alpine deformation is marked by an almost flat $\mathrm{N}$-vergent major thrust (i.e. D3 phase) responsible for the steepening of the former Jurassic detachment and nearby mineralization (Fig. 3A). Minor $\mathrm{N}$-vergent faults occur within the mineralized bodies (Fig. 3F).

\section{Mineralogy and geochemistry of MCHS}

Detailed paragenetic sequences are presented in Table S1-1 and summarized in Table 1. See also Dietrich (1972). Chemical composition of selected mineralized phases (EPMA analyses) is given in Table S2-1 and S2-2. We first describe the sequence of the mineralization in the most mineralized zones, then the one of the Snake Pit outcrop, close to the detachment plane.

Lizardite is the serpentine polymorph forming serpentinite. Small magnetite and pentlandite grains $(<100 \mu \mathrm{m})$ occur along former olivine grain boundaries or within serpentine domains, respectively (Fig. 4A). Magnetite is commonly found in replacement after Cr-spinel. Pentlandite is characterized by high $\mathrm{Ni}$ (35.84 to 36.14 wt.\%) and low Co (1.66 to $1.80 \mathrm{wt}$ \%) ) contents (with $\mathrm{Co} / \mathrm{Ni}$ ratio $\sim 0.05$, Fig. $5 \mathrm{~A}$ ). Magnetite displays high Si contents (0.43 to 1.26 wt.\%; Fig. 5B).

Toward the mineralized zones, lizardite is progressively replaced by Fe-antigorite/greenalite. Serpentinites are crosscut by Fe-Ca-silicates veins comprised of ilvaite, hydro-andradite and Fediopside $\left(\mathrm{Di}_{21}-\mathrm{Di}_{84}\right)$, associated with fibrous Fe-antigorite/greenalite, defining a stockwork structure (Fig. 4B-D). Locally, the amount of Fe-Ca-silicates increases drastically and they massively replace serpentinites along metasomatic bands (Fig. 4E). Fe-Ca-silicates can be associated with magnetite, pyrrhotite, chalcopyrite, pentlandite, sphalerite and isocubanite (Fig. 4B, D, and F). Textural relationships attest for synchronous crystallization of Fe-Ca silicates and sulfides. Locally, magnetite associated with ilvaite displays growth or dendrite-like textures indicative of contemporaneity (Fig. 4G, S1-1).

The proportion of magnetite and sulfides increases toward the most mineralized zones, defining an assemblage of semi-massive sulfides. It consists of millimetric to centimetric veins made of 
pyrrhotite and magnetite in textural equilibrium, minor chalcopyrite and pentlandite and Feantigorite/greenalite at their rims (Fig. 4H). Pentlandite has low Ni (21.3 to 24.2 wt.\%) and low Co (2.9 to 3.6 wt.\%) contents (with $\mathrm{Co} / \mathrm{Ni}$ ratio $\sim 0.15$, Fig. 5A). Pyrrhotite displays intermediate Ni contents (average $\sim 2800$ ppm, Fig. 5C). Secondary oxidation minerals are pyrite/marcasite, violarite, bornite and covellite (Fig. S1-1).

In the most mineralized zones, serpentinites are almost completely replaced by a $\mathrm{Cu}-\mathrm{Fe}-\mathrm{Ni}-\mathrm{Co}-\mathrm{Zn}-$ rich assemblage of euhedral pyrrhotite, magnetite, pentlandite, Fe-diopside and minor small sphalerite enclosed within chalcopyrite (from $20 \%$ up to $50 \%$ of the mineralization, Cu-rich MS) displaying isocubanite exsolutions. All grains are in apparent textural equilibrium (Fig. 4I). Pentlandite displays low Ni (24.9 to 25.7 wt.\%) and high Co (14.1 to 15.3 wt.\%) contents (with $\mathrm{Co} / \mathrm{Ni}$ ratio $\sim 0.58$, Fig. 5A). Pyrrhotite has low Ni contents (<2000 ppm, average $\sim 720 \mathrm{ppm}$ ).

Close to the detachment (i.e. Snake Pit), Fe-Ca-silicates are absent. The mineralization consists of disseminated euhedral pyrite grains or aggregates with minor chalcopyrite, pyrrhotite, pentlandite and sphalerite (Fig. 6B). Pentlandite displays high Ni (33 to 33.8 wt.\%) and low Co (1.4 to 1.6 wt.\%) contents (with $\mathrm{Co} / \mathrm{Ni}$ ratio $\sim 0.05$, Fig. 5A). Pyrrhotite has high Ni contents $(>3000$ ppm, average about 4700 ppm, Fig. 5C). Steeply-dipping N-S calcite veins crosscut the mineralized serpentinite (Fig. 6A). These carbonates display $\delta^{13} \mathrm{C}$ values from 0.94 to $2.35 \%$ (Table S3-1, Fig. $6 \mathrm{C}$; full range of the MCHS from -1.28 to $2.35 \%$ ) and $\delta^{18} \mathrm{O}$ values from 11.6 to $13.1 \%$ (full range of the MCHS from 11.5 to $13.1 \%$ ). Calcite veins from Snake Pit yield a Jurassic U-Pb age of 144 $\pm 13 \mathrm{Ma}$ (Fig. 6D).

\section{Discussion}

\section{1) Preservation of the MCHS during the Alpine overprint}

A recurrent problem when dealing with rift-related pre-Alpine structures in the Alps is to assess the Alpine tectonic and metamorphic overprint. At Cotschen, the Jurassic detachment and the nearby mineralization associated with dyke-like intrusions were tilted in the footwall of a Nvergent D3 thrust. Because they show roughly the same orientation as the detachment, the intrusions presently in "dyke-like" position were probably sills intruded near-parallel to the detachment and schistose serpentinites. Despite tilting, the intrusions retained their planar attitude, 
and are crosscut by only a few faults with metric offsets (Figs. 3C, D, F), indicating that the system underwent limited internal strain.

In addition, several petrographic and isotopic features show that the system is preserved. First, calcite veins crosscutting the mineralized serpentinite display carbon isotope signatures typical of present-day marine ophicalcites forming at the seafloor (Ribeiro da Costa et al., 2008; Bach et al., 2011 ); their $\delta^{18} \mathrm{O}$ around $12 \%$ is diagnostic of carbonation at temperatures around $130^{\circ} \mathrm{C}$ (temperatures already reported along neighboring Jurassic detachment; Coltat et al., 2019). Finally, these carbonates yield a Jurassic U-Pb age (Fig. 6D).

\section{2) The MCHS: a fossil root zone of UHS}

The $\mathrm{Cu}-\mathrm{Fe}-\mathrm{Ni}-\mathrm{Co}-\mathrm{Zn}$ mineralization previously reported in mafic-ultramafic settings worldwide have been attributed to either a magmatic (i.e. orthomagmatic Ni-Cu-PGE and Fe-Ti-V deposits with cumulate and mat textures in mafic-ultramafic intrusions, Foose, 1985; Song et al., 2003 ) or to a hydrothermal origin (Foose et al., 1985; Thalhammer et al., 1986; Maslennikov et al., 2017). In the present case, the transformation of lizardite into Fe-antigorite/greenalite, the stockwork structures and the metasomatic replacement of serpentinites by ore phases and $\mathrm{Fe}-\mathrm{Ca}$ silicates are diagnostic of epigenetic mineralization attesting for a hydrothermal origin.

The MCHS presents similarities with the UHS at the MAR (Table 2). Both hydrothermal systems share a geometry implying a detachment fault juxtaposing basalts onto serpentinites (McCaig et al., 2007). Mineralogical similarities are numerous: $\mathrm{Cu}-\mathrm{Fe}-\mathrm{Ni}-\mathrm{Co}-\mathrm{Zn}$ mineralization of the MCHS is typical of UHS (Fouquet et al., 2010); the replacement textures observed in the Curich MS are expected to occur in the highly altered zones close to seafloor (Marques et al., 2006); the $\mathrm{Co}$ enrichment of $\mathrm{Cu}$-rich MS pentlandite is a feature shared with pentlandite from active systems (Mozgova et al., 1996; Borodaev et al., 2007).

The presence of mafic intrusions and the lack of hydrothermal chimneys suggest that the MCHS represents the deep levels of an UHS. This is consistent with the limited size of the mineralized bodies when compared to sulfide lenses observed at UHS seafloor. Also, the mineralogical diversity recorded at the MCHS (i.e. Fe-Ca-silicates together with ore minerals) has never been reported for UHS where intensive steatization is rather observed. Similarly, the high and low proportions of magnetite and sphalerite, respectively, slightly contrast with the mineralogical assemblage described for UHS (see Fouquet et al., 2010 for a review, Table 2). We therefore 
propose that the geometric and mineralogical features of the MCHS are symptomatic of UHS root zones.

\section{3) Conceptual model}

A conceptual model for the formation of UHS based on this study is proposed in figure 7. During mantle exhumation, downward infiltration of seawater induced pervasive serpentinization of the peridotites (Fig. 7A). The resulting fluids were likely focused all the way to the seafloor along the detachment. The inception and cooling of gabbroic bodies and associated dyke and sill networks at depth likely triggered hydrothermal circulation. Fluids circulated along faults cutting through basalts and into the permeable serpentinite basement where they interacted with rocks (Marques et al., 2006; McCaig et al., 2007) (Fig. 7A). The resulting acidic, reduced and hot black smoker-type fluids reacted with serpentinization-derived fluids to form the mineralogical assemblage reported at the MCHS (Fig. 7A). Upward fluid circulation was enhanced along maficultramafic interfaces; mafic intrusions acted as drains. In the deepest parts, Fe-Ca-silicates crystallized together with ore minerals. In the upper part, close to the detachment (Snake Pit), these silicates were no longer stable, possibly because of the circulation of oxidized seawater that increased $f_{\mathrm{O} 2}$ and enhanced pyrite stabilization.

On the deepest parts, the mineralogical zonation from barren serpentinite to Fe-Ca-silicates to semi-massive sulfides and then to Cu-rich MS (Figs. 3E, 7B) has never been reported before this study. The ilvaite-andradite-diopside assemblage has been described in low-grade metamorphic serpentinites (Agata and Agachi, 1995) and in oceanic ultramafic settings (Gaggero et al., 1995). Gaggero et al. (1995) suggested that this assemblage precipitated from early serpentinizationderived fluids. Gustafson (1974) showed that the ilvaite-hedenbergite-andradite-magnetite assemblage is stable at low $f_{\mathrm{O} 2}\left(10^{-25}\right.$ to $\left.10^{-32}\right)$, high- $\mathrm{T}\left(425 \pm 75^{\circ} \mathrm{C}\right)$ conditions without strong changes if considering diopside instead of hedenbergite. In parallel, the semi-massive sulfides and $\mathrm{Cu}$-rich MS mineralogy suggests precipitation from acidic, reduced and hot $\left(>350^{\circ} \mathrm{C}\right)$ fluids, which would have probably interacted with mafic rocks (McCaig et al., 2007) as well as ultramafic rocks to explain $\mathrm{Ni}$ enrichment. These conditions are compatible with those forming Fe-Ca-silicates as the formation of hydrated minerals (e.g. ilvaite, hydroandradite and actinolite) decreases the $\mathrm{pH}$ of the fluid (Allen and Seyfried, 2003). In addition, $\mathrm{CH}_{4}-$ and $\mathrm{H}_{2}$-rich venting fluids reported for UHS (Charlou et al., 2002) suggest that concomitant in-depth serpentinization 
occurred during black-smoker-related hydrothermal activity. We thus propose that the horizontal zonation observed at depth results from increasing fluid/rock ratios from the outer zones to the stockwork zone then to the most mineralized zones.

Finally, the cooling of the system is recorded through Late Jurassic hydrothermal carbonation $\left(\sim 130^{\circ} \mathrm{C}\right)$ close to the detachment plane. Previous studies have emphasized that carbonation could derive from the mixing between serpentinization-derived uprising fluids (along the detachment) and seawater close to the seafloor (Kelley et al., 2001; Ludwig et al., 2006). The $\delta^{13} \mathrm{C}$ values of the MCHS ophicalcites are similar to those reported at the Lost-City hydrothermal field suggesting that the same mechanism could have caused carbonate precipitation in the MCHS.

\section{Conclusions}

The distribution of mineralized assemblages across the Marmorera-Cotschen Hydrothermal System records the subsurface evolution of an ultramafic-hosted hydrothermal system, from a $\mathrm{Cu}-$ Fe-Ni-Co-Zn-rich assemblage and associated Fe-Ca-silicates in the deepest zones to a sulfide-rich, silicate-free mineralization close to the detachment plane. Carbonation marked the end of the hydrothermal circulation. The MCHS formed in a hyper-extended margin. This suggests that black smoker-type hydrothermal activity is not restricted to oceanic domains but can also occur in Ocean-Continent Transitions, which should lead us to reconsider metal resources available in such geodynamic settings.

\section{Acknowledgments}

The authors would like to thank J. Langlade for help with microprobe analyses, X. Lecoz for the preparation of thin sections. We acknowledge Andrew Martin and one anonymous reviewer for their constructive reviews. This study was founded through CNRS-INSU and University of Rennes 1 “Défis Scientifiques” grants (accorded to P. Boulvais and R. Coltat).

\section{Data Availability Statement}

The data that support the findings of this study are provided in the supplementary material.

\section{References}


Agata, T., and Adachi, M., 1995. Ilvaite from a serpentinized peridotite in the Asama igneous complex, Mikabu greenstone belt, Sambagawa metamorphic terrain, central Japan: Mineralogical Magazine, 59, 489-496.

Allen, D. E., and Seyfried, W. E., 2003. Compositional controls on vents fluids from ultramafichosted hydrothermal systems at mid-ocean ridges: an experimental study at $400^{\circ} \mathrm{C}, 500$ bars: Geochimica et Cosmochimica Acta, 67, 1531-1542, doi:10.1016/S0016-7037(02)01173-0

Alt, J.C., Crispini, L., Gaggero, L., Levine, D., Lavagnino, G., Shanks, P., and Gulbransen, C., 2018. Normal faulting and evolution of fluid discharge in a Jurassic seafloor ultramafic-hosted hydrothermal system: Geology, 46, 523-526, doi:org/10.1130/G40287.1

Bach, W., Rosner, M., Jöns, N., Rausch, S., Robinson, L.F., Paulick, H., and Erzinger, J., 2011. Carbonate veins trace seawater circulation during exhumation and uplift of mantle rock: Results from ODP Leg 209: Earth and Planetary Science Letters, 311, 242-252, doi:10.1016/j.eps1.2011.09.021

Bill, M., O’Dogherty, L., Guex, J., Baumgartner, P. O., and Masson, H., 2001. Radiolarite ages in Alpine-Mediterranean ophiolites: Constraints on the oceanic spreading and the Tethys-Atlantic connection: Geological Society of America Bulletin, 113, 129-143, doi:10.1130/00167606(2001)113<0129:RAIAMO >2.0.CO;2

Boillot, G., et al., 1987. Tectonic denudation of the upper mantle along passive margins; a model based on drilling results (ODP Leg 103, western Galicia margin, Spain): Tectonophysics, 132, 335-342, doi:10.1016/0040-1951(87)90352-0

Borodaev, Y. S., Bryzgalov, I. A., Mozgova, N. N., and Uspenskaya, T., Y., 2007. Pentlandite and Co-enriched pentlandite as characteristic minerals of modern hydrothermal sulphide mounds hosted by serpentinized ultramafic rocks (Mid-Atlantic Ridge): Moscow University Geological Bulletin, 62, 85-97, doi:10.3103/S0145875207020032

Bortnikov, N.S., Vikentyev, I. V., Apollonov, V. N., Stavrova, O. O., Bogdanov, Y. A., Lein, A. Y., Gurvich, E. G., Sagalevich, A. M., Simonov, V. A., and Ikorskii, S. V., 2001. The Rainbow serpentinite-hosted hydrothermal field, Mid-Atlantic Ridge, $36^{\circ} 14^{\prime} \mathrm{N}$ : Mineralogical and geochemical features: Mineral Deposits at the Beginning of the 21st Century, 265-268 
Charlou, J. L., Donval, J. P., Fouquet, Y., Jean-Baptiste, P., and Holm, N., 2002. Geochemistry of high $\mathrm{H} 2$ and $\mathrm{CH} 4$ vent fluids issuing from ultramafic rocks at the Rainbow hydrothermal field (36²14'N, MAR): Chemical Geology, 191, 345-359, doi:10.1016/S0009-2541(02)00134-1

Coltat, R., Boulvais, P., Branquet, Y., Collot, J., Epin, M.E., and Manatschal, G., 2019. Syntectonic carbonation during syn-magmatic mantle exhumation at an ocean-continent transition: Geology, 47, 183-186, https://doi.org/10.1130/G45530.1

Desmurs, L., Müntener, O., and Manatschal, G., 2002. Onset of magmatic accretion within a magma-poor rifted margin: a case study from the Platta ocean-continent transition, eastern Switzerland: Contrib. Mineral. Petrol., 144, 365-382. doi:10.1007/s00410-002-0403-4

Dietrich, V., 1972, Die sulfidischen Vereezungen in den Oberhalbsteiner Serpentiniten: Geotechnische Serie, 49, 129pp.

Douville, E., Charlou, J.L., Oelkers, E.H., Bienvenu, P., Jove Colon, C.F., Donval, J.P., Fouquet, Y., Prieur, D., and Appriou, P., 2002. The rainbow vent fluids ( $\left.36^{\circ} 14^{\prime} \mathrm{N}, \mathrm{MAR}\right)$ : the influence of ultramafic rocks and phase separation on trace metal content in Mid-Atlantic Ridge hydrothermal fluids: Chemical Geology, 184, 37-48.

Dunoyer de Segonzac, G., and Bernoulli, D., 1976. Diagénèse et métamorphisme des argiles dans le Rhétien Sud-Alpin et Austro-alpin (Lombardie et Grisons): Bulletin de la Société géologique de France, 18, 1283-1293.

Epin, M.E., 2017. Evolution morpho-tectonique et magmatique polyphasée des marges ultradistales pauvres en magma : la transition océan-continent fossile de l'Err et de la Platta (SE Suisse) et comparaison avec des analogues actuels, Unpubl. doctoral dissertation, Université de Strasbourg, Strasbourg, 340pp.

Evrard, C., Fouquet, Y., Moëlo, Y., Rinert, E., Etoubleau, J., and Langlade, J. A., 2012. Tin concentration in hydrothermal sulphides related to ultramafic rocks along the Mid-Atlantic Ridge: a mineralogical study: Eur. J. Mineral., 27, 627-638, doi:10.1127/ejm/2015/0027-2472

Ferreiro Mählmann, R., 1994. Zur Bestimmung von Diagenesehöhe und beginnender Metamorphose: Temperaturgeschichte und Tektogenese des Austroalpins und Südpenninikums in Vorarlberg und Mittelbünden, Institut für Geochemie, Petrologie und Lagerstättenkunde der Johann Wolfgang Goethe Universität. 
Firstova, A., Stepanova, T., Cherkashov, G., Goncharov, A., and Babaeva, S., 2016. Compositions and formation of gabbro-peridotite hosted seafloor massive sulfide deposits from the Ashadze-1 hydrothermal field, Mid-Atlantic Ridge: Minerals, 19, 20pp, doi:10.3390/min6010019

Foose, M. P., 1985. The setting of a magmatic sulfide occurrence in a dismembered ophiolite, southwest Oregon: U.S. Geol. Surv. Bull., 1626A

Foose, M. P., Economou, M., and Panayiotou, A., 1985. Compositional and mineralogic constraints on the genesis of ophiolitic hosted nickel mineralization in the Pevkos area, Limassol forest, Cyprus: Mineralium Deposita, 20, 234-240

Fouquet, Y., et al., 2008. Serpentine Cruise - ultramafic hosted hydrothermal deposits on the MidAtlantic Ridge: First submersible studies on Ashadze 1 and 2, Logatchev 2 and Krasnov vents fields: InterRidge News, 17, 16-21

Fouquet, Y., et al., 2010. Geodiversity of hydrothermal processes along the Mid-Atlantic Ridge and ultramafic-hosted mineralization: a new type of oceanic $\mathrm{Cu}-\mathrm{Zn}-\mathrm{Co}-\mathrm{Au}$ volcanogenic massive sulphide deposit: Geophysical Monograph Series, 188, 321-367

Froitzheim, N., Schmid, S. M., and Conti, P., 1994. Repeated change from crustal shortening to orogen-parallel extension in the Austroalpine units of Graubünden: Eclogae Geologicae Helvetiae, 87/2, 559-612, doi.org/10.5169/seals-167471

Froitzheim, N., and Manatschal, G., 1996. Kinematics of Jurassic faulting, mantle exhumation, and passive-margin formation in the Austroalpine and Penninic nappes (eastern Switzerland): GSA Bulletin, 108, 1120-1133

Gaggero, L., Cortesogno, L., and Gazzoti, M., 1997. Data Report: Oxides, sulphides and associated phases in veins and hydrothermally altered peridotitic rocks. In: Proceedings of the Ocean Drilling Program (Karson, J.A., Cannat, M., Miller, D.J., and Elthon, D.). Scientific Results, 153, 523-529

Goodfellow, W. D., and Franklin, J. M., 1993. Geology, mineralogy, and chemistry of sedimenthosted clastic massive sulfides in shallow cores, Middle Valley, Northern Juan de Fuca Ridge: Economic Geology, 88, 2037-2068 
Gustafson, W. I., 1974. The stability of andradite, hedenbergite and related minerals in the system Ca-Fe-Si-O-OH: Journal of Petrology, 15, 455-96

Hannington, M. D., Tivey, M. K., Larocque, A. C. L., Petersen, S., and Rona, P. A., 1995. The occurrence of gold in sulfide deposits of the TAG hydrothermal field, Mid-Atlantic Ridge: Can. Mineral., 33, 1285-1310.

Herzig, P.M., Petersen, S., and Hannington, M., 1998. Geochemistry and sulfur-isotopic composition of the TAG hydrothermal mound, Mid-Atlantic Ridge, $26^{\circ} \mathrm{N}^{\prime}$ : Proceedings of the Ocean Drilling Program, Scientific Results, 158, 47-70

Kelley, D. S., et al., 2001. An off-axis hydrothermal vent field near the Mid-Atlantic Ridge at $30^{\circ} \mathrm{N}$ : Nature, 412, 145-149.

Ludwig, K. A., Kelley, D. S., Butterfield, D. A., Nelson, B. K., and Früh-Green, G., 2006. Formation and evolution of carbonate chimneys at the Lost City hydrothermal field: Geochimica et Cosmochimica Acta, 70, 3625-3645, doi:10.1016/j.gca.2006.04.016

Marques, A.F.A., Barriga, F., Chavagnac, V., and Fouquet, Y., 2006. Mineralogy, geoschemistry and Nd isotope composition of the Rainbow hydrothermal field, Mid-Atlantic Ridge: Mineralium Deposita, 41, 52-67, DOI 10.1007/s00126-005-0040-8

Maslennikov, V. V., et al., 2017. Chimneys in Paleozoic massive sulfide mounds of the Urals VMS deposits: Mineral and trace element comparison with modern black, grey, white and clear smokers: Ore Geology Reviews, 85, 64-106, doi:10.1016/j.oregeorev.2016.09.012

McCaig, A.M., Cliff, R.A., Escartin, J., Fallick, A.E., and McLeod, C.J., 2007. Oceanic detachment faults focus large volumes of black smoker fluids: Geology, 35, 935-938, doi:10.1130/G23657A

McCaig, A.M., Delacour, A., Fallick, A.E., Castelain, T., and Gretchen, F.G., 2010. Detachment fault control on hydrothermal circulation systems: interpreting the subsurface beneath the TAG hydrothermal field using the isotopic and geological evolution of oceanic core complexes in the Atlantic: Geophysical Monograph Series, 188, 207-239 
Mozgova, N. N., Krasnov, S. G., Batuyev, B. N., Borodaev, Y. S., Efimov, A. V., Markov, V. F., and Stepanova, T., V., 1996. The first report of cobalt pentlandite from a Mid-Atlantic Rige hydrothermal deposit: The Canadian Mineralogist, 34, 23-28.

Nehlig, P., and Marquez, L., 1998. Feeder zones of massive sulfide deposits: Constraints from Bent Hill, Juan de Fuca Ridge - ODP Leg 169: Water-rock interaction, 751-754

Nickel, E. H., Ross, J. R., and Thornber, M. R., 1974. The supergene alteration of pyrrhotitepentlandite ore at Kambalda, Western Australia: Economic Geology, 69, 93-107.

Ondreas, H., Cannat, M., Fouquet, Y., and Normand, A., 2012. Geological context and vents morphology of the ultramafic-hosted Ashadze hydrothermal areas (Mid-Atlantic Ridge $13^{\circ} \mathrm{N}$ ): Geochemistry, Geophysics, Geosystems, 13, 20pp, doi:10.1029/2012GC004433

Pinto,V. H. G., Manatschal, G., Karpoff, A. M., and Viana, A., 2015. Tracing mantle-reacted fluids in magma-poor rifted margins: the example of Alpine Tethyan rifted margins:

Geochemistry, Geophysics, Geosystems, 16, 3271-3308, doi:10.1002/2015GC005830.

Ribeiro da Costa, I., Barriga, F. J. A. S., and Taylor, R. N., 2008. Late seafloor carbonate precipitation in serpentinites from the Rainbow and Saldanha sites (Mid-Atlantic Ridge): Eur. J. Mineral., 20, 173-181, doi:10.1127/0935-1221/2008/0020-1803

Rona, P. A., and Scott, S. D., 1993. A special issue on sea-floor hydrothermal mineralizations: new perspectives: Economic Geology, 88, 1935-1976

Schaltegger, U., Desmurs, L., Manatschal, G., Müntener, O., Meier, M., Frank, M., and Bernoulli, D., 2002. The transition from rifting to sea-floor spreading within a magma-poor rifted margin: field and isotopic constraints: Terra Nova, 14, 156-162, doi:10.1046/j.1365-3121.2002.00406.x

Song, X.-Y., Zhou, M.-F., Cao, Z.-M., Sun, M., and Wang, Y.-L., 2003. Ni-Cu-(PGE) magmatic deposits in the Yangliuping area, Permian Emeishan igneous province, SW China: Mineralium Deposita, 38, 831-943, doi:10.1007/s00126-003-0362-3

Thalhammer, O., Stumpfl, E. F., and Panayiotou, A., 1986. Postmagmatic, hydrothermal origin of sulfide and arsenide mineralizations at Limassol forest, Cyprus: Mineralium Deposita, 21, 95-105 
Tucholke, B. E., Lin, J., and Kleinrock, M. C., 1998. Megamullions and mullion structure defining oceanic metamorphic core complexes on the Mid-Atlantic Ridge: Journal of Geophysical Research, 103, 9857-9866

\section{Figure captions}

Figure 1. (A) Simplified genetic model proposed for the formation of active ultramafic-hosted black-smokers deposits (e.g. Rainbow-type systems) along slow-spreading ridges showing the speculated fluid pathway (after McCaig et al., 2007). Seawater percolates through fractures and faults crosscutting the mafic cover and circulates through the permeable serpentinite basement where it gets heated in the vicinity of the gabbroic intrusions before rising up in the serpentinized footwall. The fluid thus discharges the metals by mixing with cold seawater. NVZ=Neo Volcanic Zone. (B) Seafloor expression of hydrothermal venting activity at the Rainbow field (2200 m.b.s.l., photo from Ifremer).

Figure 2. (A) Simplified map of the main paleogeographic units of the Central and Western Alps and the Apennines. (B) Geological map of the Platta nappe (modified after Schaltegger et al., 2002) showing the Marmorera Cotschen area (black inset). (C) Reconstructed cross section shows mantle exhumation beneath the Adriatic plate during the Jurassic WNW-ESE-oriented opening of the Alpine Tethys Ocean (after Pinto et al., 2015). Mantle exhumation recorded in the Platta nappe was accommodated by detachment faults and was accompanied by mafic magmatism (gabbros, dolerites and basalts). As a consequence of a low magmatic budget, large parts of the seafloor expose mantle rocks without the establishment of a Penrose-type oceanic crust.

Figure 3. (A) General view of the cliff of the Marmorera-Cotschen hydrothermal system. The mineralization is distributed almost continuously from the Marmorera Lake (bottom of the picture, $1684 \mathrm{~m}$ above sea level (m.a.s.)) up to Cotschen (2308 m.a.s.) exposing about $600 \mathrm{~m}$ of vertical relief. (B) Line-drawing of the picture displayed in (A) At most places, the serpentinite-hosted mineralization occurs as thin corridors (up to several meters) while the main gossan has a width of 90 meters. (C) Relationship between dyke-like south-dipping mafic intrusions and mineralization in the upper gossan. Mineralization is hosted in the serpentinite on the southern flank of each intrusion, resulting in a repeated S-N spatial sequence of mineralized serpentinite, the mafic intrusion and barren serpentinite (grassy areas). (D) Actinolite-rich (Act) alteration at a mafic intrusion - mineralized serpentinite interface in the upper gossan. (E) On the margin of mafic 
intrusions intruding the serpentinites at Marmorera, occurrence of a hydrothermal zonation evolving from $\mathrm{Cu}$-rich massive sulfide ( $\mathrm{Cu}$-rich $\mathrm{MS}$ ) and semi-massive sulfide to barren serpentinite. (F) Top-to-the-NNW reverse fault (D3 Alpine phase) displacing by a few meters a planar mafic intrusion in the upper gossan.

Figure 4. Micrographs illustrating the mineralogical evolution from the barren serpentinites to the $\mathrm{Cu}$-rich MS (i.e. approaching the mafic intrusions). (A) Barren serpentinite exhibiting early small $(<50 \mu \mathrm{m})$ magnetite (Mt I) and pentlandite (Pn I) grains along serpentine (Srp I) grain boundaries and within serpentine domains, respectively. Location in figure 3E. (B) Ilvaite (Ilv) and Fediopside (Dp) veins enclosing chalcopyrite (Cp) and magnetite (Mt II) grains from a Fe-Casilicates stockwork structure. Some magnetite grains are also found in the serpentine groundmass without specific relationship to Fe-Ca-silicates. (C) Typical Fe-Ca-silicates stockwork structure cutting through serpentinites. (D) Zoom on the internal composition of the stockwork shown in figure 4C. It consists of ilvaite (Ilv) and minor Fe-diopside (Dp) veins. The serpentine groundmass contains small disseminated grains or aggregates of sphalerite and pentlandite $(\mathrm{Pn}+\mathrm{Sp})$. Smaller sulfide grains $(<25 \mu \mathrm{m}$, not visible on that scale) are also present in the Fe-Ca-silicates veins, which suggests that sulfides formed before the silicate stockwork. Spinel (Spn) relics persist in the serpentine groundmass. (E) Extensive metasomatic replacement of serpentinite by Fe-Ca-silicates and associated sulfides and oxides. (F) Sulfide aggregate made of sphalerite (Sp), chalcopyrite (Cp) with isocubanite (Is) exsolutions, and magnetite (Mt II). The aggregate is surrounded by an assemblage of magnetite, hydroandradite (Adr) and ilvaite (Ilv). White arrows point to dendriticlike intergrowths of magnetite and ilvaite, suggesting a concomitant crystallization of the two phases. (G) Growth texture attesting for a synchronous crystallization of magnetite (Mt II) and ilvaite (Ilv). Chalcopyrite ( $\mathrm{Cp}$ ) is locally present within ilvaite. (H) Semi-massive sulfide made of magnetite (Mt II) and pyrrhotite (Po) veins associated with a newly formed serpentine phase (Srp II, likely Fe-antigorite or greenalite). Location in figure 3E. (I) $\mathrm{Cu}$-rich massive sulfides with an assemblage made of chalcopyrite (Cp) with isocubanite (Is) exsolutions, pyrrhotite (Po), magnetite (Mt II), pentlandite (Pn II) and Fe-diopside (Dp) enclosing serpentine clasts (Srp II). Location in figure $3 \mathrm{E}$.

Figure 5. Elemental discriminant diagrams for pentlandite (A) and magnetite (B) grains from the MCHS and present-day occurrences at the MAR. (A) Co vs. Ni (wt. \%) diagram for pentlandite from the MCHS plotted together with Co-rich pentlandite from seafloor $\mathrm{Cu}$-rich chimneys at the 
MAR (Mozgova et al., 1996). The increase in intensity of the hydrothermal alteration intensity increase is marked an increase of the $\mathrm{Co} / \mathrm{Ni}$ ratio. The loss of $\mathrm{Ni}$ in pentlandite from semi-massive sulfides likely reflects the alteration of pentlandite into violarite (Nickel et al., 1974). (B) Si (ppm) vs. Fe (wt. \%) diagram for magnetite from Marmorera and magnetite from the Rainbow hydrothermal field (this study). Compared to syn-serpentinization magnetite (green squares, $4000<\mathrm{Si}<13000 \mathrm{ppm}$ ), syn-mineralization magnetite (all other squares) has lower Si contents (< 6200 ppm, average around 1900 ppm). (C) Frequency histogram of Ni content (ppm) for pyrrhotite from the MCHS. The mean composition of several pyrrhotite grains from different hydrothermal assemblages of Rainbow (MAR) is also shown (Marques et al., 2006). A negative correlation between the $\mathrm{Ni}$ content of pyrrhotite and the intensity of the hydrothermal alteration is visible in both the active (i.e. Rainbow) and fossil (i.e. MCHS) systems.

Figure 6. Features associated with carbonation in the serpentinites right beneath the Jurassic detachment (Snake Pit and Marmorera outcrops, located in figure 3A and B). (A) Mineralized serpentinite crosscut by sub-vertical calcite veins. (B) Pyrite (Py) + chalcopyrite $(\mathrm{Cp})$ aggregate hosted in serpentine (Srp) and crosscut by late calcite (Cc). (C) $\delta^{13} \mathrm{C}$ vs. $\delta^{18} \mathrm{O}$ isotopic diagram of ophicalcites from the MCHS and present-day marine ophicalcites from the $15^{\circ} 20^{\prime} \mathrm{N}$ Fracture Zone at MAR (Bach et al., 2011). $\delta^{13} \mathrm{C}$ signatures of the ophicalcites from the MCHS overlap with those from the MAR. In contrast, $\delta^{18} \mathrm{O}$ signatures of the ophicalcites from the MCHS are much lower than those from the MAR, reflecting different temperatures of formation for the two systems. (D) Tera-Wasserburg diagram for calcite grains from sample Cot16_49 at Snake Pit (LA-ICP-MS U$\mathrm{Pb}$ analyses). The analyses are discordant and lie on a linear trend with a lower intercept date at $144 \pm 13 \mathrm{Ma}$. Ellipsoids are displayed with a confidence of $\pm 2 \sigma$.

Figure 7. (A) Genetic model for the formation of the MCHS before carbonation hydrothermal stage. During mantle exhumation along a detachment, seawater percolates downward through the faulted mafic hangingwall and the damaged serpentinite footwall where it leaches metals (the exact sources need further investigation). The heat transferred from cooling of shallow gabbroic bodies triggers hydrothermal convection. The fluids get heated and rise in the damage zone of the detachment likely up to the surface where metal deposition from the fluids form UHS. Fluid circulation is guided by lithological interfaces such as the contacts between mafic intrusions and serpentinites. Synchronously, at greater depth, active serpentinization of peridotite releases fluids which, on their way to the surface, likely mix with black smoker-type fluids, forming the 
mineralogical assemblage reported in this study. (B) Schematic view of the mineralogical zonation occurring on the margin of mafic dykes, ranging from barren serpentinite to an envelope of $\mathrm{Fe}-\mathrm{Ca}-$ silicates stockwork, to semi-massive sulfides and ultimately $\mathrm{Cu}$-rich MS. The transition between fresh lizardite-rich serpentinite and the Fe-Ca-silicates stockwork is marked by the replacement of lizardite by a Fe-rich serpentine (likely Fe-antigorite). The overall zonation likely reflects an increase of the fluid/rock ratio from the outer parts (i.e. barren serpentinite) to the inner part (i.e. $\mathrm{Cu}$-rich MS) of the system.

\section{Table captions}

Table 1. Synthetic paragenetic sequence of the mineralization observed at Marmorera-Cotschen (left) compared to the one observed at the Snake Pit outcrop (right). Fe-Ca-silicates (underlined in the Marmorera-Cotschen sequence, left) are absent at Snake Pit, pyrite and calcite (in bold underlined in the Snake pit sequence) are absent at Marmorera-Corschen. See text and supplementary data for details.

Table 2. Main characteristics of present-day and fossil oceanic hydrothermal systems

\section{Supplementary material}

Supporting information includes the caption for figure S1-1.

Tables S1, S2 and S3 can be found in files Table S1-1.pdf, Table S1-2.pdf, Table S2-1.pdf, Table S2-2.pdf, Table S3-1.pdf, Table S3-2.pdf and Table S3-3.pdf. 
Table 2. Main characteristics of present-day and fossil oceanic hydrothermal systems

\begin{tabular}{|c|c|c|c|c|c|c|}
\hline Hydrothermal system & Rainbow & Logatchev 1 & Ashadze 1 & TAG & Bent-Hill & $\begin{array}{c}\text { Fossil MCHS } \\
\text { (this study) }\end{array}$ \\
\hline Location & MAR $36^{\circ} 14^{\prime} \mathrm{N}$ & MAR $14^{\circ} 45^{\prime} \mathrm{N}$ & MAR $12^{\circ} 58^{\prime} \mathrm{N}$ & MAR $26^{\circ} 08^{\prime} \mathrm{N}$ & $\begin{array}{l}\text { Middle Valley rift; N } \\
\text { Juan de Fuca Ridge }\end{array}$ & Platta nappe, Swiss Alps \\
\hline Host rocks & Serpentinite & Serpentinite & Serpentinite & MORB & Turbidites & Serpentinite \\
\hline Mineralization type & $\mathrm{Cu}-\mathrm{Zn}-\mathrm{Co}-\mathrm{Au}$ & $\mathrm{Cu}-\mathrm{Zn}-\mathrm{Fe}-\mathrm{Ni}-\mathrm{Co}$ & $\mathrm{Zn}-\mathrm{Cu}-\mathrm{Fe}-\mathrm{Ni}-\mathrm{Co}$ & $\mathrm{Fe}-\mathrm{Zn}-\mathrm{Cu}$ & $\mathrm{Fe}-\mathrm{Cu}-\mathrm{Zn}$ & $\mathrm{Cu}-\mathrm{Fe}-\mathrm{Ni}-\mathrm{Co}-\mathrm{Zn}$ \\
\hline Tectonic setting & $\begin{array}{l}\text { Nontransform offset, } \\
\text { ultramafic dome }\end{array}$ & East valley wall & $\begin{array}{l}\text { West rift valley wall, } \\
\text { detachment fault }\end{array}$ & $\begin{array}{l}\text { Rift wall, } \\
\text { volcanic centers }\end{array}$ & Rift valley & $\begin{array}{l}\text { Serpentinized } \\
\text { detachment footwall }\end{array}$ \\
\hline Type of mineralization & Chimneys + MS & Mound + chimneys & Chimneys + MS & Mound & Chimneys + MS & Stockwork + MS \\
\hline Size (m) & $400 \times 100$ & $400 \times 150$ & 200 & $250 \times 250 \times 45$ & $400 \times 400 \times 60$ & 90 x 90 (max.) \\
\hline $\begin{array}{l}\text { Main hydrothermal } \\
\text { phases }\end{array}$ & Is, $\mathrm{Cp}, \mathrm{Sp}, \mathrm{Po}, \mathrm{Pn}, \mathrm{Au}$ & $\mathrm{Cp}, \mathrm{Is}, \mathrm{Sp}, \mathrm{Py}, \mathrm{Pn}$ & $\mathrm{Cp}, \mathrm{Sp}, \mathrm{Is}, \mathrm{Po}, \mathrm{Bn}$ & Py, An, Cp, (Sp) & Py, Po, Cp, Sp & $\begin{array}{l}\text { Cp, Po, Mt, Ilv, Ad, Dp, } \\
\text { Pn, Is, Sp }\end{array}$ \\
\hline References & $\begin{array}{l}\text { Fouquet et al., 2010; } \\
\text { Marques et al., 2006; } \\
\text { Charlou et al., 2002; } \\
\text { Bortnikov et al., } 2001\end{array}$ & $\begin{array}{l}\text { Fouquet et al., 2010; } \\
\text { Evrard et al., 2015; } \\
\text { Fouquet et al., } 2008\end{array}$ & $\begin{array}{l}\text { Fouquet et al., 2010; } \\
\text { Fouquet et al., 2008; } \\
\text { Ondreas et al., 2012; } \\
\text { Firstova et al., } 2016\end{array}$ & $\begin{array}{l}\text { Fouquet et al, 2010; } \\
\text { Herzig et al., 1998; } \\
\text { Rona and Scott, 1993; } \\
\text { Hannington et al., } 1995\end{array}$ & $\begin{array}{l}\text { Nehlig and Marquez, } \\
\text { 1998; Goodfellow and } \\
\text { Franklin, } 1993\end{array}$ & $\begin{array}{l}\text { Dietrich, 1972; } \\
\text { This study }\end{array}$ \\
\hline
\end{tabular}

In bold are displayed the hydrothermal phases which differ from present-day systems The elements displayed in the mineralization type are given by modal abundance

Is=isocubanite, $\mathrm{Cp}=$ chalcopyrite, $\mathrm{Sp}=$ sphalerite, $\mathrm{Po}=$ pyrrhotite, $\mathrm{Pn}=$ pentlandite, $\mathrm{Py}=$ pyrite, $\mathrm{Bn}=$ bornite, $\mathrm{An}=$ anhydrite, $\mathrm{Mt}=$ magnetite, Ilv=ilvaite, $\mathrm{Ad}=\mathrm{hydroandradite}, \mathrm{Dp}=\mathrm{diopside}, \mathrm{MS}=$ massive sulphide

This article is protected by copyright. All rights reserved 


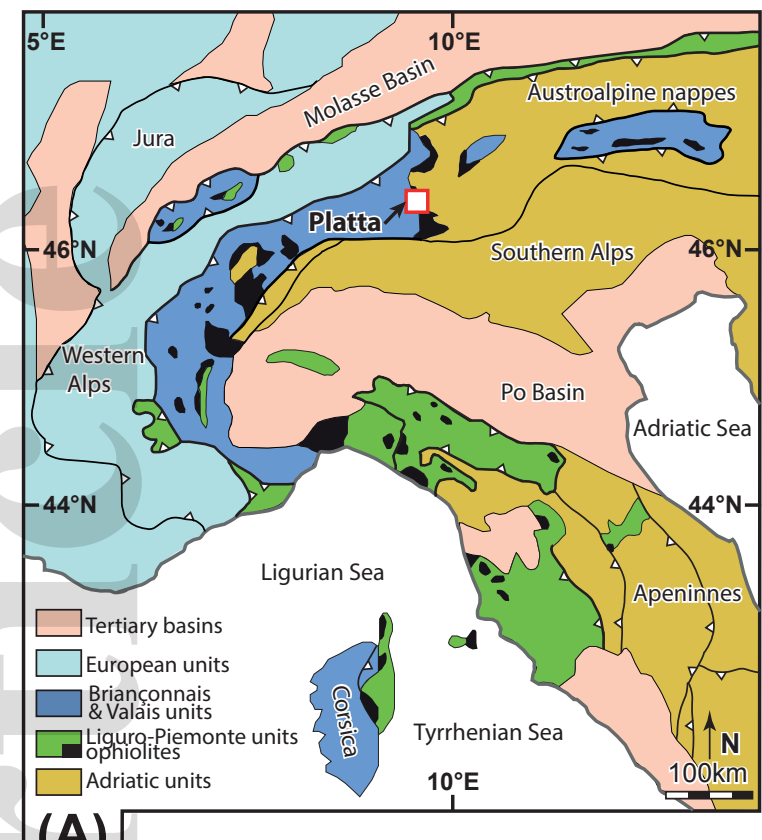

(A)
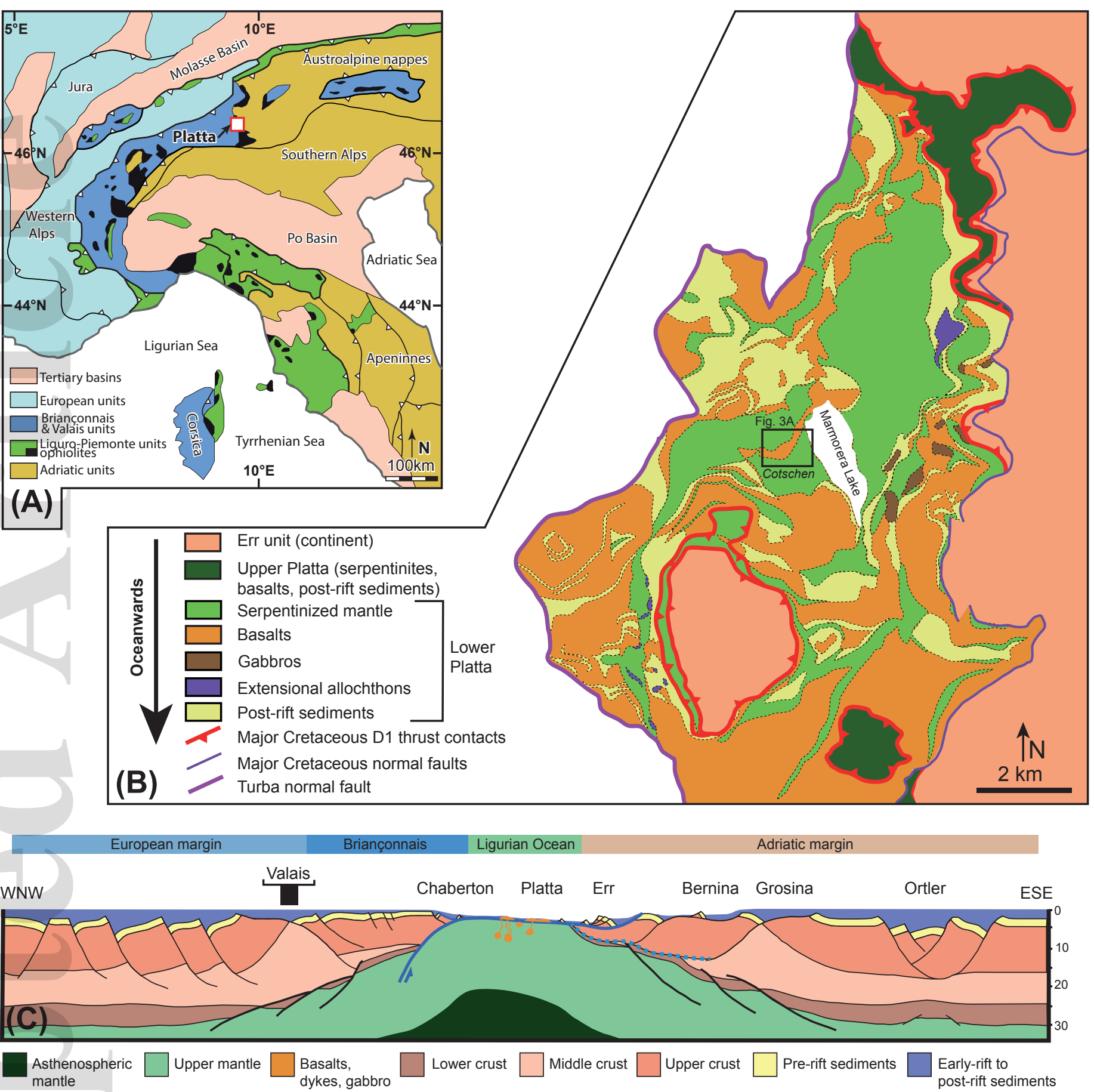

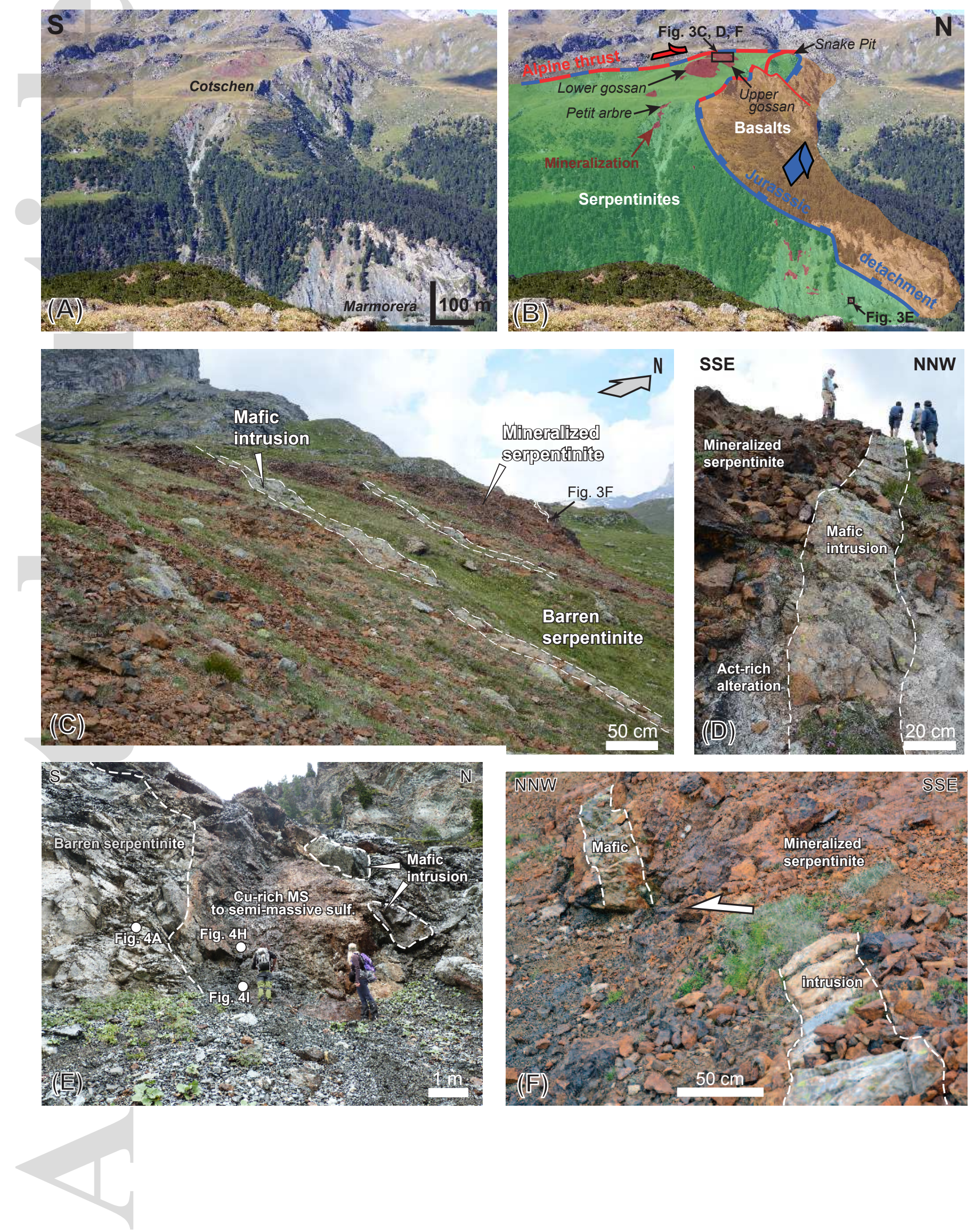

This article is protected by copyright. All rights reserved 
ter_12427_f4.pdf
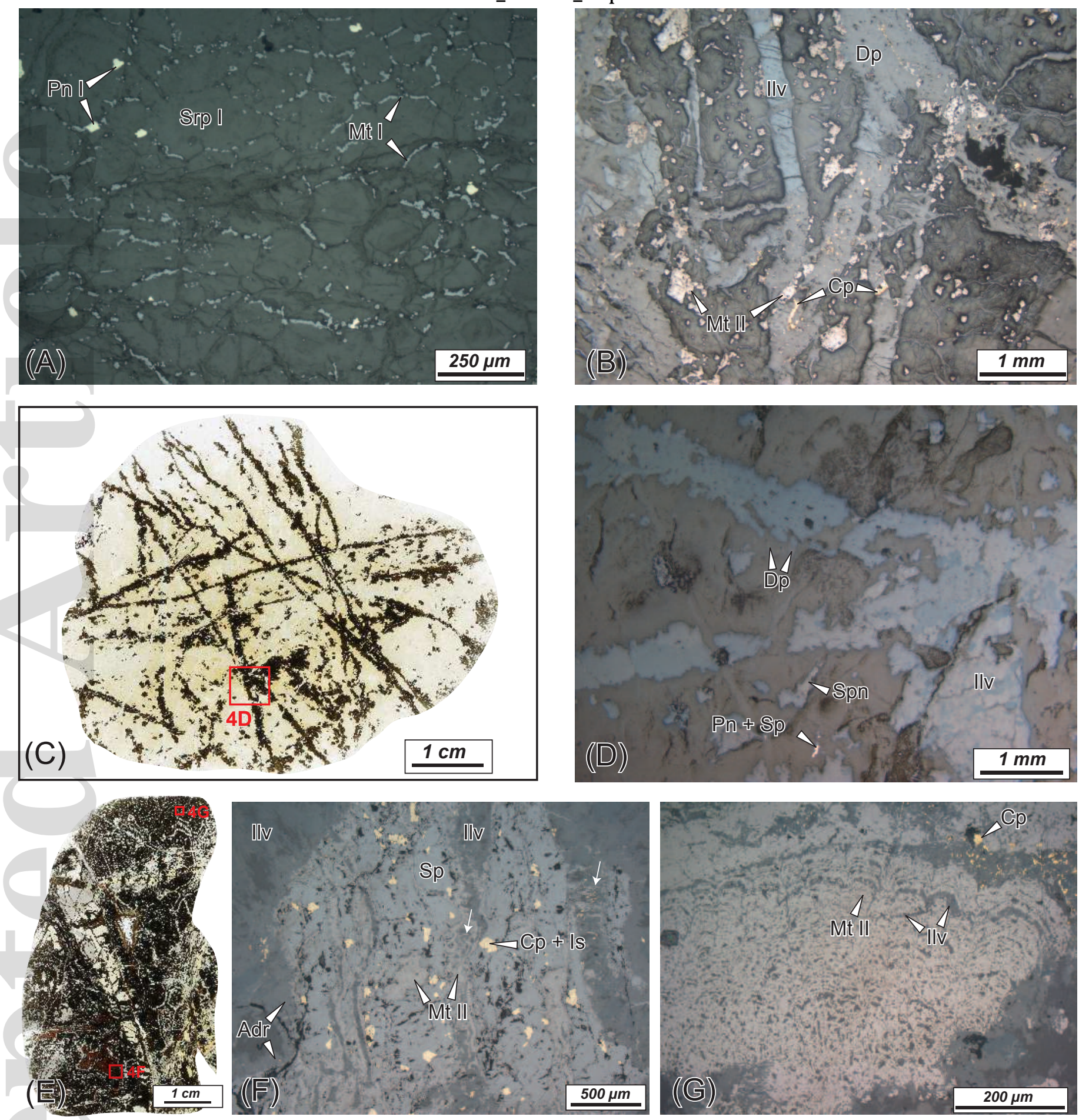

$500 \mu \mathrm{m}$
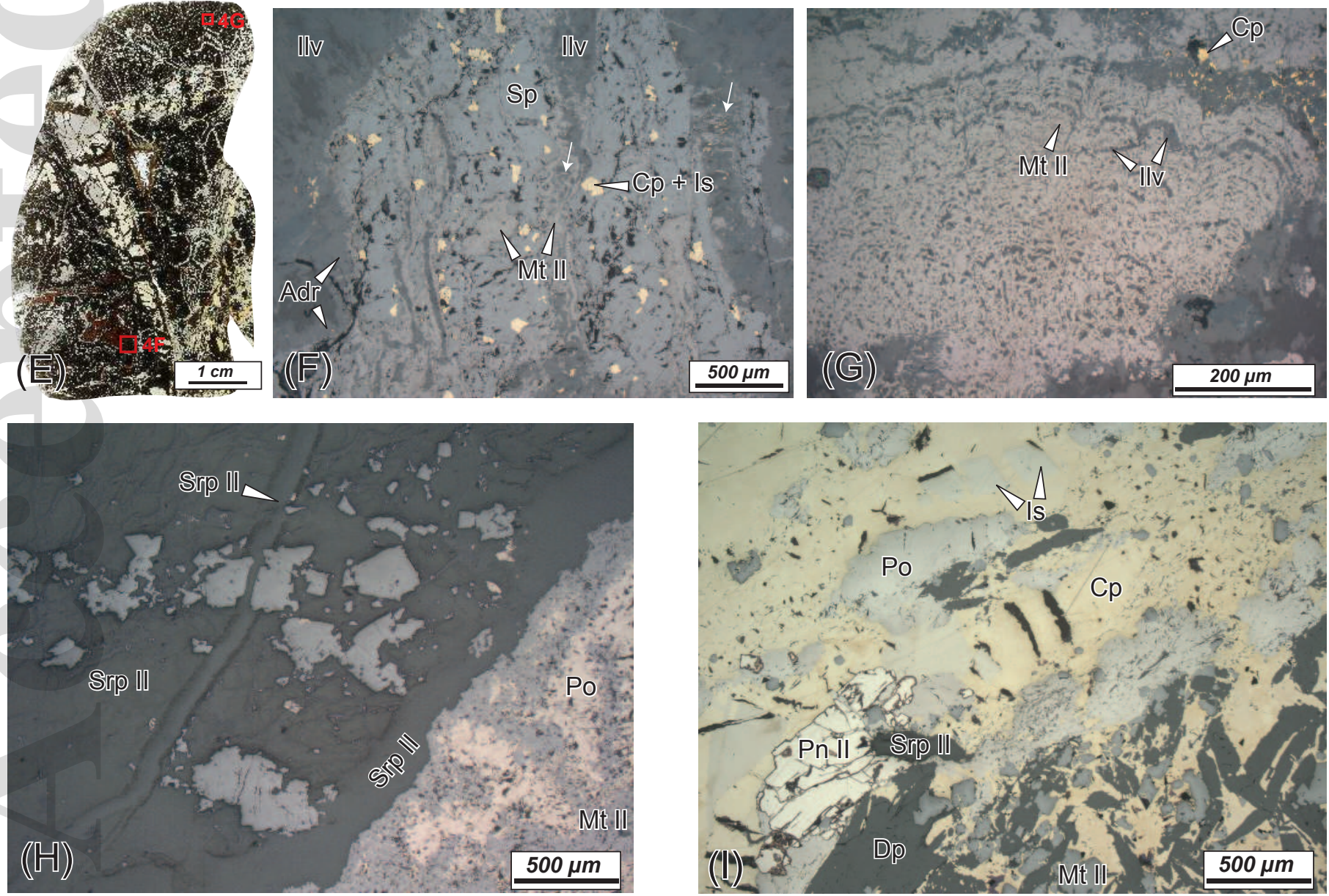

This article is protected by copyright. All rights reserved 

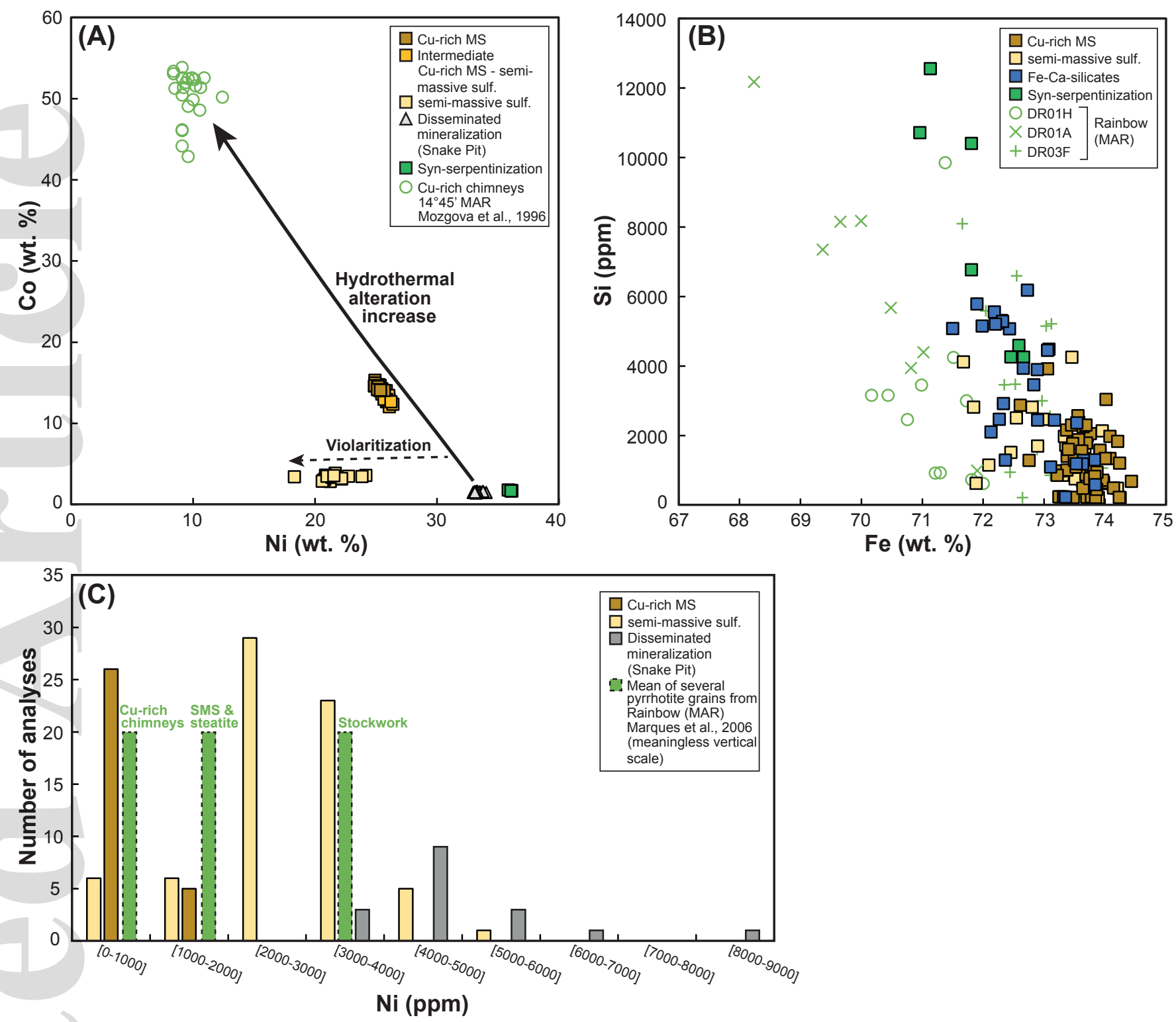

This article is protected by copyright. All rights reserved 

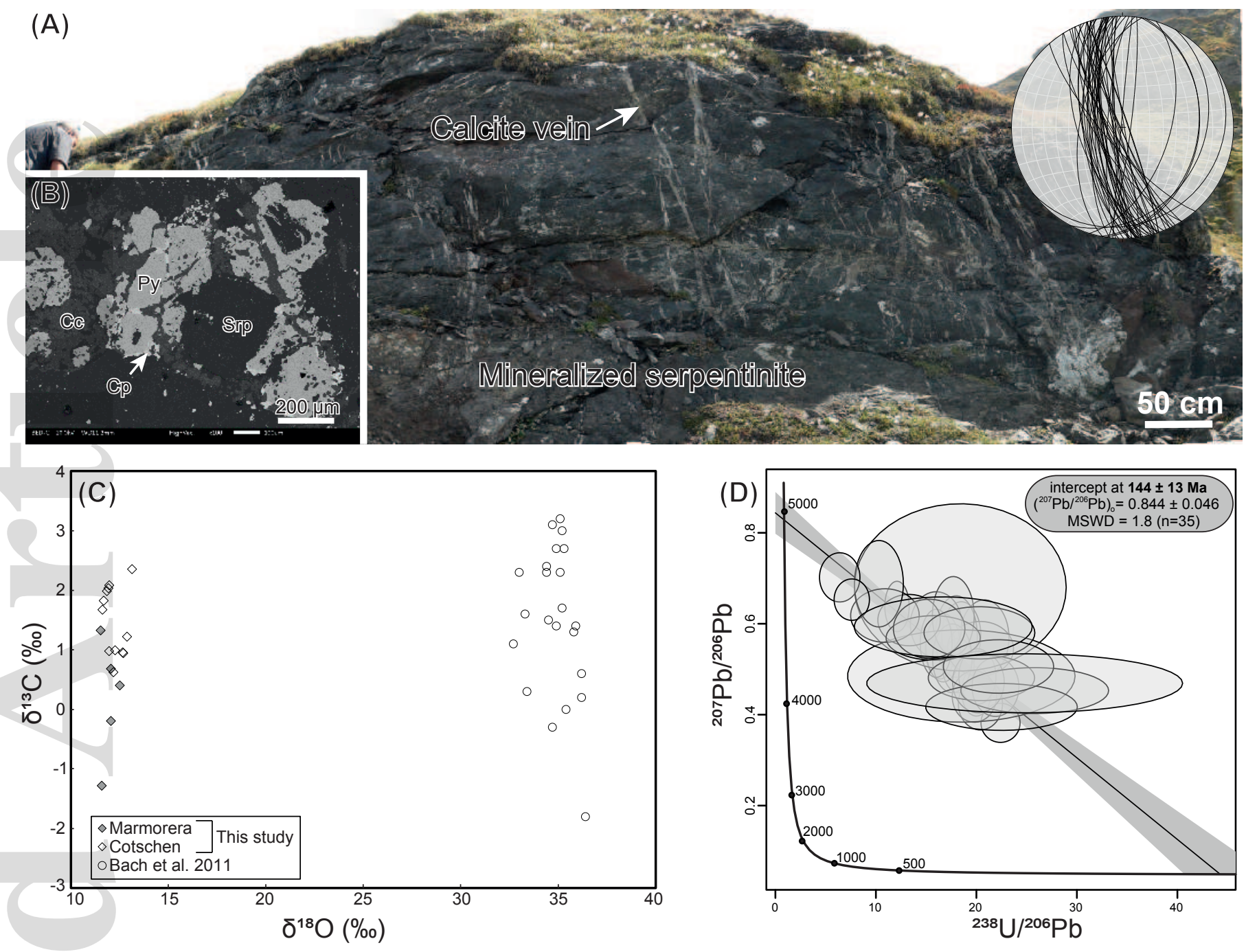

This article is protected by copyright. All rights reserved 


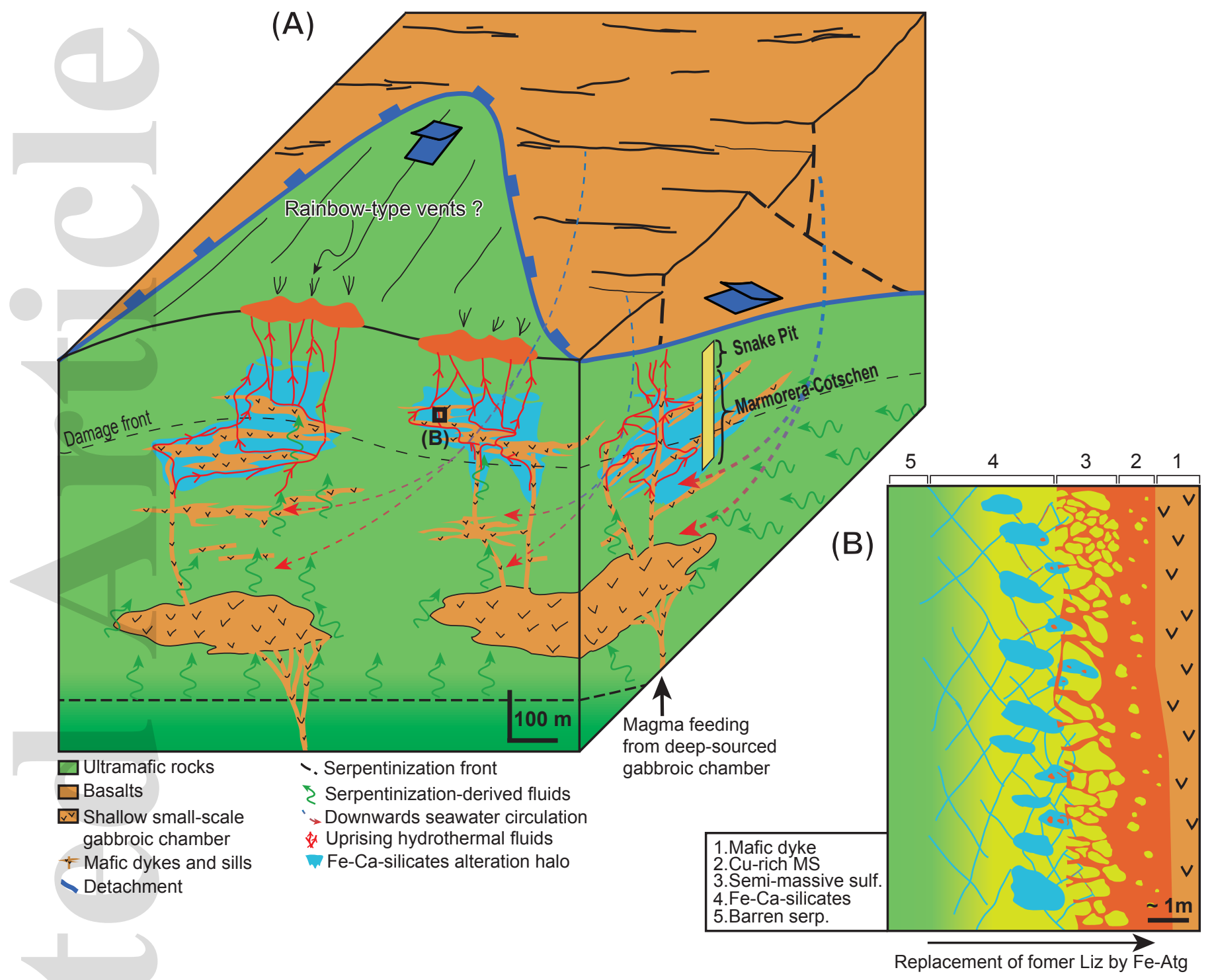

